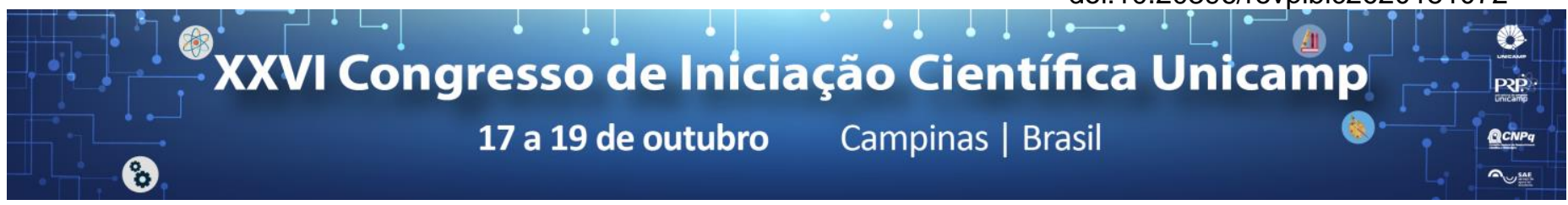

\title{
Estudo do papel do receptor AhR na função imunomoduladora da Vitamina D3 na geração de células dendríticas tolerogênicas.
}

\section{Natália Brunetti Silva*, Fernando Pradella, Carolina Francelin Rovarotto, Alessandro dos Santos Farias.}

\begin{abstract}
Resumo
A Esclerose Múltipla é uma doença autoimune crônica e desmielinizante, que envolte fatores genéticos e ambientais. Acredita-se que dentre esses fatores está a deficiência de Vitamina D3. Anteriormente, nós demonstramos que as células dendríticas (DCs) são o principal alvo de regulação da vitamina, induzindo um perfil tolerogênico das DCs dependente da expressão de IDO. Essas DCs IDO+ induzem o aumento e a estimulação de linfócitos T CD4+FOXP3+ com ação reguladora, diminuido a resposta inflamatória no modelo experimental (EAE). A IDO gera quinureninas, que serão reconhecidas pelo receptor aril hidrocarboneto (Ahr) gerando uma resposta imunossupressora. Assim, nosso objetivo foi verificar a participação dos produtos da IDO expressa por células dendríticas tolerogênicas, geradas na presença da vitamina D3, na indução de células T regulatórias.
\end{abstract}

\section{Palavras-chave:}

Vitamina D3, Receptor Aril Hidrocarboneto, Autoimunidade.

\section{Introdução}

A Esclerose Múltipla (EM) é uma doença autoimune crônica e desmielinizante que acomete o Sistema Nervoso Central (SNC) ${ }^{1}$. A encefalomielite autoimune experimental (EAE) é o mais bem definido modelo experimental da EM. Dentre os fatores ambientais relacionados está a baixa produção e/ou ingestão de Vitamina D3. ${ }^{2}$ Sua produção pode se dar pela exposição solar da pele ou através da transformação pelas células dendríticas. Recentemente, nós demonstramos que as células dendríticas (DCs) são o principal alvo de regulação da vitamina $D_{3}$, que induz um perfil tolerogênico nas DCs dependente da expressão da IDO. Essas DCs IDO+ induzem o aumento e a estimulação de linfócitos T CD4+Foxp3+ com ação reguladora, in vivo. Esse recrutamento de Treg diminui a resposta inflamatória da EAE. ${ }^{3} \mathrm{~A}$ enzima IDO é capaz de degradar o Triptofano e gerar quinureninas, um ligante natural do receptor aril hidrocarboneto $(\mathrm{AhR}) .^{4}$ Este receptor é um fator de transcrição que pode atuar na supressão da resposta imune tumoral, na diferenciação de células $T$ reguladoras $\mathrm{Foxp}^{+}$e na diminuição da imunogenicidade das células dendríticas. ${ }^{5}$

Desta forma, é possível que os produtos do metabolismo da IDO possam agir diretamente sobre as células $T$ atuando na conversão e/ou manutenção das Treg e/ou na manutenção do perfil tolerogênico das DCs de forma autócrina. O nosso objetivo neste estudo é analisar a participação dos produtos da IDO das células dendríticas tolerogênicas, cultivadas na presença da vitamina $D_{3}$, sobre a geração de Tregs.

\section{Resultados e Discussão}

- Estabelecimento da cultura de células dendríticas a partir de precursores obtidos na medula óssea de tíbias e fêmures de camundongos C57BL/6J e tratamento das mesmas com Vitamina D3.

- PCR quantitativo em tempo real para verificar a expressão gênica do receptor $A h R$ e da enzima IDO. Apenas a expressão de GAPDH foi significativa para diversas amostras. Demais genes não apresentaram expressões detectáveis.

- Transferência adotiva de DCs tolerogênicas geradas a partir de animais C57BL/6 WT para animais C57BL/6 WT, previamente à indução de EAE e acompanhamento da doença após 10 dias de imunização.

Figura 1. A-Precursores da medula óssea. BDiferenciação de precursores em DCs.

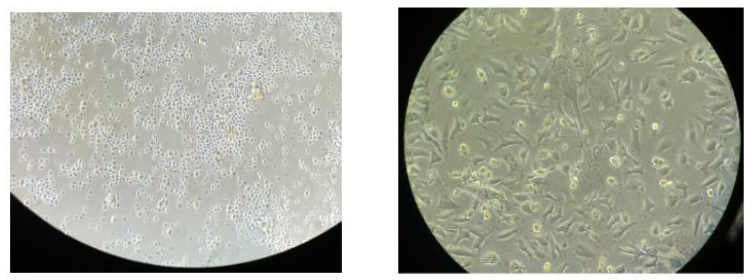

Conclusões

Nossos resultados são preliminares, o que não nos permite concluir o objetivo proposto no projeto. Como próximos passos, pretendemos realizar a pré amplificação das amostras de cDNA obtidas através das culturas de células dendríticas e posteriormente realizar o PCR quantitativo das mesmas. Assim como, repetir os experimentos de transferência de células e indução da EAE.

Agradecimentos

Agradeço ao SAE/UNICAMP pelo financiamento do projeto.

\footnotetext{
1 Nylander, A.; Hafler, D. A. Multiple sclerosis. v. 122, n. 4, p. 1180-1188, abr. 2012

${ }^{2}$ Hayes, C. E. Vitamin D: a natural inhibitor of multiple sclerosis. Proc Nutr Soc, v. 59, n. 4, p.531-535, nov. 2000.

${ }^{3}$ Farias, A. S. et al. Vitamin D3 induces IDO+ tolerogenic DCs and enhances Treg, reducingthe severity of EAE. CNS Neuroscience \&amp; Therapeutics, v. 19, n. 4, p. 269-277, abr. 2013.

${ }^{4}$ Munn, D. H.; Mellor, A. L. Indoleamine 2,3 dioxygenase and metabolic control of immuneresponses. Trends in immunology, v. 34, n. 3, p. 137-143, mar. 2013.

${ }^{5}$ Quintana, F. J.; Sherr, D. H. Aryl hydrocarbon receptor control of adaptive immunity. Pharmacological Reviews, v. 65, n. 4, p. 1148-1161, 2013.
} 